
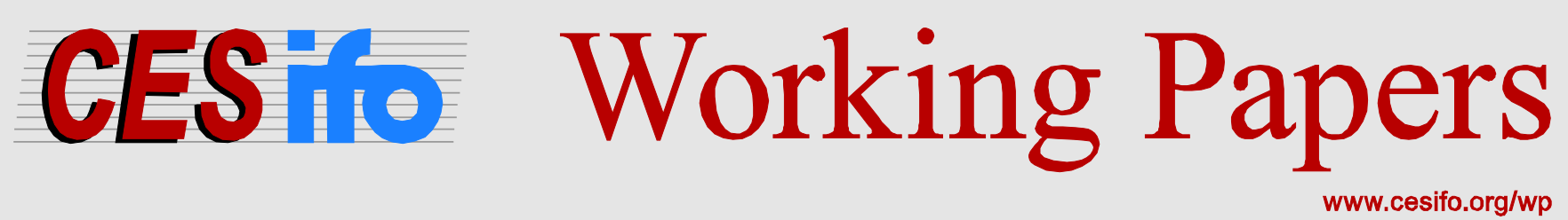

\title{
Why Countries Differ in Thin Capitalization Rules: The Role of Financial Development
}

\author{
Mohammed Mardan
}

CESIFO WORKING PAPER NO. 5295

CATEGORY 1: PUBLIC FINANCE

APRIL 2015

An electronic version of the paper may be downloaded

- from the SSRN website:

- from the RePEc website:

- from the CESifo website:

wWw.SSRN.com

www.RePEc.org

www.CESifo-group.org/wp 


\title{
Why Countries Differ in Thin Capitalization Rules: The Role of Financial Development
}

\begin{abstract}
In the absence of financial frictions, the purpose of thin capitalization rules is to limit multinational firms' possibilities of engaging in tax planning via debt shifting. This paper analyzes the effects of thin capitalization rules in the case where firms have limited access to external funding. First, we show that a host country allows positive internal interest deductions if its financial development is sufficiently low. This amount increases when the financial development of the host country worsens. Then we ask which of the two most common thin capitalization rules used in practice is better suited to maximizing welfare of the host country. We show that welfare under a safe haven rule is higher than under an earnings stripping rule if firms are not able to manipulate transfer prices. Welfare, however, can be higher under an earnings stripping rule if firms are able to manipulate transfer prices. The analysis provides an explanation for why countries differ in the strictness and in the type of thin capitalization rule.
\end{abstract}

JEL-Code: H250, G380, F230.

Keywords: thin capitalization rule, safe haven rule, earnings stripping rule, debt shifting, financial development.

\author{
Mohammed Mardan \\ Department of Management, Technology and Economics \\ ETH Zurich \\ Leonhardstrasse 21 \\ Switzerland - 8092 Zurich \\ mardan@kof.ethz.ch
}

March 2015

I thank Johannes Becker, Andreas Haufler, Onur Koska, Giorgia Maffini, Panu Poutvaara, Dirk Schindler, Davide Suverato and the participants of the Public Economics Seminar in Munich, the PET in Lisbon, the IIPF in Taormina, the 8th Norwegian-German Seminar on Public Economics in Munich and the conference on "Taxing Multinational Firms" in Mannheim for helpful comments. 


\section{Introduction}

It is well known that multinational enterprises (MNEs) can use internal debt to shift profits from low-tax to high-tax countries. ${ }^{1}$ Specifically, affiliates in low-tax countries give loans to affiliates in high-tax countries. The interest on this loan is taxable in the low-tax country and tax-deductible in the high tax country. This reduces overall tax payments by the amount of interest payments multiplied by the tax rate differential of the respective countries.

Many governments try to counteract this debt-shifting by implementing thin capitalization rules. Thin capitalization rules disallow tax deductibility of internal interest payments if the size of these expenses surpasses a permissible threshold. In this way, the use of internal debt for tax planning issues is limited, preventing an erosion of the tax base and hence tax revenue losses. The common way of introducing a thin capitalization rule is to implement a safe haven rule. Recently, however, some countries (Finland, Germany, Italy, Japan, Norway, Portugal and Spain) switched to a system of a pure earnings stripping rule. ${ }^{2}$

The main difference between the two thin capitalization rules is that the safe haven rule disallows the tax deduction of interest payments to related parties if internal debt exceeds a specified debt-to-equity ratio, whereas the earnings stripping rule restricts tax deductibility if internal interest payments exceed a certain fraction of an affiliate's EBITDA. Thus, the safe haven rule limits the amount of internal loans while the earnings stripping rule confines the value of internal interest payments.

However, there is evidence that internal capital markets are also used by MNEs to allocate internal capital to affiliates that are limited in raising external funds due to a weak financial development of the host country (Büttner et al., 2009; Desai et al., 2004; Egger et al., 2014). Previous studies showed that the access to finance is a major determinant of growth and development (Rajan and Zingales, 1998; Beck et al., 2000). Moreover, Manova (2013) shows that exporting firms and thus international trade are severely affected by financing restrictions as firm selection into production, producers' entry into exporting, and exporters' foreign sales are impeded by financial frictions.

\footnotetext{
${ }^{1}$ Empirical evidence for such tax planning behavior is given inter alia by Huizinga et al. (2008) and Egger et al. (2010).

${ }^{2}$ For a description of thin capitalization rules for most OECD and EU countries see Gouthière (2005) and Dourado and de la Feria (2008) respectively.
} 
If credit market frictions are severe so that firms cannot exploit all investment opportunities, a generous allowance to deduct internal interest payments can have large positive effects on local investments by reducing firms' costs of capital. Suggestive evidence for this prediction can be provided by comparing average deduction allowances for internal interest expenses for financially more and financially less developed countries. Using domestic credit to the private sector as a percentage of GDP as a proxy for financial development and debt-to-asset ratios for the strictness of countries' thin capitalization rules, Table 1 shows average deduction allowances for internal interest expenses for groups of countries in different stages of financial development. ${ }^{3}$ It also shows that, as the financial development of a country improves, tax deductions for internal interest payments become less generous, on average. Moreover, the recent switch from the safe haven rule to the earnings stripping rule is carried out only by countries whose financial development is not less than high.

Table 1: Strictness of thin capitalization rules and financial development ${ }^{4}$

\begin{tabular}{|l|c|}
\hline $\begin{array}{l}\text { Financial } \\
\text { development }^{a}\end{array}$ & $\begin{array}{l}\text { Average deduction allowance } \\
\text { for internal interest expenses }\end{array}$ \\
\hline Low & 0.93 \\
Moderate & 0.87 \\
High & 0.83 \\
Very high & 0.75 \\
\hline
\end{tabular}

${ }^{a}$ The four categories of financial development are defined as follows: Low (credit-to-GDP ratio: 0-40\%), moderate (40-80\%), high (80-120\%), very high $(120+\%)$. There is a total number of 116 countries in our sample ranging from a minimum credit-to-GDP ratio of $4.1 \%$ (Afghanistan) to a maximum creditto-GDP ratio of $202.8 \%$ (Denmark), with a median of $44.4 \%$ (Paraguay).

${ }^{3}$ Following the literature (Arezki and Brückner, 2012; Chinn, Eichengreen and Ito, 2014; von Hagen and Zhang, 2014), the level of financial development is measured by domestic credit to the private sector as a percentage of GDP (credit-to-GDP ratio).

${ }^{4}$ For the credit-to-GDP ratio, we use data provided by the World Bank for the year 2012 if available. Otherwise, we use the latest data available. For countries' thin capitalization rules, we collect data on debt-to-equity ratios from the European Tax Handbook (2013), the Global Corporate Tax Handbook (2013) and the Ernst \& Young Worldwide Corporate Tax Guide (2013) and convert them to debtto-asset ratios. Using the debt-to-asset ratio introduces an upper limit of unity for those countries that have no thin capitalization rule at all. For those countries which have recently switched to an earnings stripping rule, Table 1 uses the former debt-to-asset ratio. Note that we excluded tax havens 
Against this background, we set up a model in which affiliates in a high-tax country are endowed with insufficient own resources and thus need external funds for investment. The amount of available external funds depends on affiliates' resources and the country's financial development. The implication of a low financial development is a credit market friction that renders low-productivity affiliates to be financially constrained, i.e. they cannot exploit all investment opportunities. More productive affiliates have more resources and can raise more external funds.

We show that the optimal amount of internal interest deductions is positive when the financial development of a country is sufficiently weak. Moreover, the optimal thin capitalization rule gets more generous if the financial development of the country worsens. The reason is that a lenient thin capitalization rule indirectly improves the ability of financially constrained affiliates to raise external funds. This prediction of the model is consistent with the fact that, on average, countries with a weak financial development have a more lenient thin capitalization rule.

We then go one step further and ask which of the two most common thin capitalization rules used in practice should be implemented to maximize the welfare of a country. The main difference between the two rules is that the safe haven rule allows the deduction internal interest payments if a specified debt-to-equity ratio is not surmounted, whereas the earnings stripping rule permits deductibility if a certain fraction of the affiliate's EBITDA is not crossed. We show that, under a safe haven rule, welfare is higher when MNEs cannot engage in internal interest manipulation. This is because the earnings stripping rule favors/discriminates financially unconstrained/constrained affiliates more than a safe haven rule. However, when MNEs are able to manipulate the transfer price, welfare under an earnings stripping rule can be higher if the host country's financial development is sufficiently high and tax revenues are more important than affiliates' profits. The reason is that a safe haven rule only restricts the amount of internal debt whereas the earnings stripping rule restricts the value of internal interest payments. These results give an explanation of why most countries have implemented a safe haven rule but also of why the switch to an earnings stripping rule is only observed for financially advanced countries.

Our analysis combines three strands of the literature. The first strand analyses preferential tax treatment of mobile tax bases and its effects on profit shifting. Peralta as defined by the IMF as their tax policy is fundamentally different to the tax policy of non-tax haven countries'. 
et al. (2006) show that a lenient control of profit shifting can reduce tax competition when governments cannot tax discriminate between multinational and domestic firms. In a general equilibrium model, Hong and Smart (2010) find that citizens of high-tax countries benefit if MNEs are allowed to shift some profits into a tax haven. Janeba and Smart (2003) establish conditions under which a restriction on preferential tax regimes decreases tax revenues. Mintz and Smart (2004) find support that the elasticity of taxable income with respect to tax rates is significantly higher for corporate subsidiaries that may engage in income shifting.

The second strand empirically investigates the effects of thin capitalization rules on the firms' financial structure. Weichenrieder and Windischbauer (2008), Overesch and Wamser (2010), Büttner et al. (2012), Wamser (2014) and Blouin et al. (2014) analyze the effectiveness of the safe haven rule. They all find that debt-to-equity ratios significantly decline when the thin capitalization rule has been tightened. Dreßler and Scheuering (2012) and Buslei and Simmler (2012) investigate the effects of a change from a fixed debt-to-equity ratio to an earnings stripping rule in Germany in the year 2008. They find that the introduction of the new rule lowered firms' debt-to-assets ratios and their net interest payments. ${ }^{5}$ In the theoretical literature, the paper by Haufler and Runkel (2012) is the only one that addresses thin capitalization rules in detail. ${ }^{6}$ They find that thin capitalization rules can be used as a policy instrument in tax competition. Smaller countries set less strict thin capitalization rules because they face a more elastic tax base. However, a crucial assumption is that firms have unlimited access to external funding. In contrast, our model allows us to study optimal thin capitalization rules in the presence of credit market frictions.

The third strand considers finance constraints in a taxation environment. Keuschnigg and Ribi (2013) analyse the impact of profit taxes under different tax systems when firms are financially constrained. They conclude that profit taxes have first order welfare effects even when tax rates are low. Egger et al. (2014) theoretically analyze several determinants of internal debt and test these empirically using data of German multinationals. Due to the incorporation of financing restrictions they find a significantly

\footnotetext{
${ }^{5}$ For an overview of thin capitalization rules and a summary of the economic effects, see Ruf and Schindler (2012).

${ }^{6}$ Fuest and Hemmelgarn (2005) concentrate on the relationship between corporate and personal income taxation but keep the thin capitalization rule fixed. In an extension, Hong and Smart (2010) endogenously derive the optimal thin capitalization rule of a small open economy with profit shifting MNEs.
} 
higher tax semi-elasticity of internal debt than typically found in other studies. Most closely related to our work is the one by Keuschnigg and Devereux (2013), who set up a model of financing frictions and offshoring of intermediate inputs. They find that the underlying arm's-length price introduces a flawed benchmark and can reduce world welfare. The reason is that high transfer prices and low royalty payments of MNEs are misinterpreted as tax induced profit shifting, even though these choices are efficient for overcoming financing constraints. The main difference to our paper is that Keuschnigg and Devereux (2013) analyze government actions to curb profit shifting of a financially advanced country. We instead, focus on the optimal tax policy of a financially less developed country. This implies that in our model thin capitalization rules solve a trade-off between limiting firms' debt shifting and correcting for institutional weaknesses in the financial sector of the host country.

This paper is structured as follows. Section 2 introduces the basic model for our analysis. Section 3 analyzes the optimal thin capitalization rules in a framework with credit market frictions. Section 4 compares the two most common thin capitalization rules, i.e. the safe haven debt-to-equity ratio and the earnings stripping rule. Section 5 gives a brief discussion and Section 6 concludes.

\section{The model}

\subsection{The basic framework}

We consider a simple one-period model of two small countries, labeled 1 and 2, and assume $t_{1}>t_{2}$ so that country 1 is the high-tax country. Capital is perfectly mobile across countries so that the rate of return of capital is fixed at $r>0$. There is a continuum of multinational enterprises (henceforth MNE) in the economy. Each MNE has one affiliate in the tax haven country 2 and one affiliate in the high-tax country 1. Affiliates in country 2 merely act as a lending basis. Hence, there is no production and we refer to these affiliates as the financial centers. Production takes place only in the high-tax country 1. The headquarters (henceforth HQ) of MNC $j$ endows the financial center with the necessary equity $E_{2}^{j}$ to provide the producing affiliate with the needed internal capital and to reach a tax-efficient financial structure.

$\theta^{j}$ denotes the productivity of affiliate $j$ in country $1 .{ }^{7}$ Productivity across MNEs differs

\footnotetext{
${ }^{7}$ For convenience, we abstain from country indices whenever possible.
} 
in the sense that $\theta^{j}$ is distributed according to a cumulative distribution function $G(\theta)$ and a density function $g(\theta)$ with support on $[\underline{\theta}, \bar{\theta}]$. A higher value of $\theta^{j}$ refers to a higher productivity. Each affiliate invests $K^{j}$ units of capital to produce $\theta^{j} f\left(K^{j}\right)$ units of a homogeneous good for the world market at a world price normalized to one. The production function exhibits the usual properties of positive but decreasing returns, i.e. $f^{\prime}\left(K^{j}\right)>0>f^{\prime \prime}\left(K^{j}\right)$. Affiliates in country 1 are exogenously endowed with $E_{1}^{j}$ units of equity. Equity has to be raised from investors. We assume that investors have to decide in which of the affiliates to invest before the productivity parameter $\theta^{j}$ is drawn. As affiliates do not differ at this stage, investors are indifferent in which of them they invest. As a result, each producing affiliate is initially endowed with the same amount of equity $E$.

We assume that investment opportunities exceed own funds $\left(K^{j}>E\right)$. Hence, a financing gap arises that has to be filled by internal debt $D_{I}^{j}$ or external funds $D_{E}^{j}{ }^{8}$ Investment is therefore financed by $K^{j}=E+D_{I}^{j}+D_{E}^{j}$.

External funds have to be raised from the national credit market. Due to agency (moral hazard) considerations, affiliates can borrow up to an amount which is proportional to their own funds

$$
D_{E}^{j} \leq \lambda\left(E+D_{I}^{j}\right)
$$

where $\lambda \geq 0 .{ }^{9}$ In the extreme case where $\lambda=0$, the credit market collapses and affiliates can only invest their own funds. For $\lambda \rightarrow \infty$ affiliates can raise as much external funds as they want, meaning that the credit market is perfect. Thus, the credit multiplier $\lambda$ can be interpreted as the financial development of the country. A higher value of $\lambda$ reflects a higher financial development of the country. ${ }^{10}$ Furthermore, we assume perfect competition among external lenders so that the interest rate charged equals the world interest rate $r$, resulting in a credit multiplier that is constant for all affiliates.

Additionally, MNEs can internally shift capital to their producing affiliate. In the baseline model, we assume that MNEs do not charge a higher premium on their loans than the external lenders. This implies that MNEs cannot use interest pricing as a means of

\footnotetext{
${ }^{8}$ New equity as a source of finance is ruled out. Empirically, new equity as a form of financing investments is small, see Bond (2000).

${ }^{9}$ For a similar approach, see Evans and Jovanovic (1989), Bernanke and Gertler (1989), Aghion et al. (2004) and Matsuyama (2007).

${ }^{10} \mathrm{~A}$ moral-hazard based relationship between the capital market and the financial development can be found in Holmstrom and Tirole (1997) and Aghion et al. (1999).
} 
profit shifting. ${ }^{11}$ In contrast to external funds, internal loans can be used to minimize the global tax bill of the MNE by shifting profits from the high-tax country to the low tax country. In fact, a loan from an affiliate in a low-tax country to an affiliate in a high-tax country increases tax payments in the low-tax country due to a higher interest income. However, the tax base in the high-tax country decreases by more if interest payments are deductible.

In general, countries can reduce this incentive by implementing controlled-foreigncorporation rules along with thin-capitalization rules. These rules limit the use of preferential tax regimes by overriding the tax-exemption principle and taxing passive income (e.g. interest payments) according to the tax credit method if certain conditions are met. ${ }^{12}$ One of these conditions is that the returns from passive investments exceed a certain fraction of total returns. Generally, income from borrowing and lending is deemed passive unless the resident shareholder proves that all of the capital is raised from unrelated persons and is lent to an active affiliated business. MNEs can circumvent the CFC rule by misrepresenting income from internal lending operations as income from external lending operations. However, this misrepresentation is costly for the MNE because additional effort is needed to conceal this behavior. We model this by specifying a convex cost function $C\left(D_{I}^{j}\right)$, with $C^{\prime}, C^{\prime \prime}>0$.

In our model, affiliates have to pay taxes in the source country. Corporate income taxes are modeled as proportional taxes on profits. We assume that the tax-exemption principle is generally applicable in our model. Therefore, repatriated profits are taxexempt in the home country of the HQ. ${ }^{13}$

\section{$2.2 \quad$ Firms}

True economic profits of producing affiliates is given by revenue from the sale of the output good minus cost of capital

$$
\rho_{1}^{j}=\theta^{j} f\left(K^{j}\right)-r K^{j} .
$$

Taxable profits of the producing affiliate amount to

$$
\rho_{1}^{j t}=\theta^{j} f\left(K^{j}\right)-r D_{E}^{j}-\min \left(r D_{I}^{j}, \phi^{j}(z)\right) .
$$

\footnotetext{
${ }^{11}$ We relax this assumption and analyze its implications in section 4.2.

${ }^{12}$ See Haufler et al. (2014) for a theoretical analysis of controlled-foreign-corporation rules.

${ }^{13}$ In the European Union, for example, this is ensured by the Parent-Subsidiary Directive. For a recent discussion and analysis see Becker and Fuest (2010).
} 
Each producing affiliate has to pay taxes proportional to its sales and incurs the cost of capital. In principle, both external and internal interest payments are tax-deductible. However, deductibility of internal interest payments is limited by a thin capitalization rule which we denote by $z$. As the primary purpose of thin capitalization rules is to restrict profit shifting in multinational firms, we assume that the government specifies the thin capitalization rule for internal debt only. ${ }^{14}$ This thin capitalization rule permits the deductibility of internal interest payments up to a threshold $\phi^{j}(z)$, which can be firm-specific. Any further interest payments of internal debt are not deductible from the tax base.

Profits of the financial center are

$$
\rho_{2}^{j}=-t_{2} r D_{I}^{j}-C\left(D_{I}^{j}\right)
$$

Since there is no production in the tax haven country, the financial center runs an economic loss in the amount of $-t_{2} r D_{I}^{j}$ because the income from interest payments is taxed while the opportunity cost of equity is not deductible from the tax base. Additionally internal loans create costs of $C\left(D_{I}^{j}\right)$ which the financial center has to bear.

As we are analyzing a tax policy under credit market frictions, we assume that for some affiliates the limitation of external funds confines their level of investment. This means that these affiliates would like to invest more because the marginal return on investment is higher than the marginal cost, but are constrained by the inability to raise further external funds.

This leaves us with the question which affiliates are hit harder by the financial constraint: the ones that are more or the one that are less productive. Generally, the answer to the question is ambiguous because there are two opposing effects of a higher productivity. First, a higher productivity increases the marginal return on capital $\theta^{j} f^{\prime}\left(K^{j}\right)$, which makes an affiliate, ceteris paribus, financially more constrained. In other words, for a given amount of capital an affiliate's level of investment is further away from its optimum. Second, however, HQs have a bigger incentive to allocate internal loans to

\footnotetext{
${ }^{14}$ In practice, we observe that several countries impose a threshold on total debt, i.e. the sum of internal and external debt. However, it is often difficult to qualitatively distinguish these two financing sources. Therefore, the specification based on total debt is administratively easier. In the case where an affiliate exceeds the specified threshold, a distinction between internal and external debt is drawn and only interest paid on external loans is allowed to be deducted. Eventually, the thin capitalization rule's target is the tax-deductibility of internal interest payments, as specified in our analysis.
} 
their producing affiliate because of the higher return on capital. This brings down the marginal return on capital directly due to more internal debt and indirectly because it enables an affiliate to raise more external funds. The extra amount of external funds an affiliate can raise due to the increase in internal loans depends on the host country's financial development. If its financial development is not too weak, the marginal return on capital $\theta^{j} f^{\prime}\left(K^{j}\right)$ decreases the higher the productivity parameter $\theta^{j}$ is. ${ }^{15}$ This means that the level of investment of more productive affiliates is closer to their first-best level of investment than that of less productive affiliates' ${ }^{16}$

Indeed, empirical evidence tells us that larger firms are less affected by finance constraints than smaller firms. Beck et al. (2008) as well as Demirgüç-Kunt and Maksimovic (1998) find that smaller firms depend more on external funds than larger firms. Brown et al. (2011) and Detragiache et al. (2008) find that foreign banks are more likely to lend to large firms than to small, opaque firms. In the following, we will therefore assume that $\lambda$ is sufficiently large.

Let us denote the productivity of the affiliate whose amount of external funds are just sufficient to reach the first-best level of investment by $\hat{\theta}$. Affiliates with a higher productivity are financially unconstrained meaning that they can raise enough external capital, to make sure that their investment is first-best. ${ }^{17}$

Each MNE's HQ chooses the amount of internal loans that maximizes the overall profits of the MNE. Using (2), (3) and (4), the MNE's overall profits are

$$
\pi^{j}=\left(1-t_{1}\right) \theta^{j} f\left(K^{j}\right)-r K^{j}+t_{1} r D_{E}^{j}+t_{1} \min \left(r D_{I}^{j}, \phi^{j}(z)\right)-t_{2} r D_{I}^{j}-C\left(D_{I}^{j}\right)
$$

Financially unconstrained affiliates use internal loans for the sole reason of minimizing their tax payments. Hence, their maximization process can be seen as a two stage process. In a first step, internal loans are allocated in order to optimize the financial structure and, in a second step, the affiliate chooses a specific amount of external funds in order to attain the first-best level of investment. As external debt is tax-deductible this is the case when the marginal return on capital $\theta^{j} f^{\prime}\left(K^{j}\right)$ equals the marginal cost of capital $r$.

\footnotetext{
${ }^{15}$ In the Appendix, we derive an explicit threshold for $\lambda$ under which this is true.

${ }^{16}$ Obviously, the marginal return is not strictly monotonically decreasing. Once affiliates reach their first-best level of investment, the effective marginal return is constant and equal to the cost of capital $r$.

${ }^{17}$ For convenience, we will call affiliates with $\theta^{j} \geq \hat{\theta}$ financially unconstrained affiliates and affiliates with $\theta^{j}<\hat{\theta}$ financially constrained affiliates.
} 
In contrast, financially constrained affiliates use internal debt also to increase their investment levels. Differentiating (5) with respect to $D_{I}^{j}$ implicitly defines the optimal amount of internal loans

$$
\left(1-t_{1}\right) \theta^{j} f^{\prime}\left(K^{j}\right)-r+\left(\mu t_{1}-t_{2}\right) r-C^{\prime}\left(D_{I}^{j}\right) \leq 0, \quad \forall \theta^{j}<\hat{\theta}
$$

where $\mu$ is a dummy variable that takes the value of unity if the marginal unit of internal interest payment is tax-deductible and zero otherwise.

\section{Optimal thin capitalization rule}

We assume that the government maximizes national welfare which is a weighted average of domestic tax revenues and the sum of all producing affiliates' profits ${ }^{18}$

$$
W_{1}=t_{1} T_{1}+\varepsilon \Pi_{1}
$$

where $T_{1}$ is the total tax base in country $1, \Pi_{1}$ is the sum of resident affiliates' profits and $0 \leq \varepsilon \leq 1$ is the relative welfare weight placed on affiliates' profits. The welfare discount on affiliates' profits either reflects the fact that raising corporate tax revenue is important for society (either for redistributive reasons or to reduce other distortive taxes), or that affiliates are partly owned by foreign investors that do not enter the welfare function. If $\varepsilon=0$, there is a 'Leviathan' government that is solely interested in maximizing its tax revenues. Furthermore, we assume, for simplicity that national tax rates are exogenous. ${ }^{19}$

The tax base of country 1 consists of the sum of the revenues of all affiliates. This tax base is reduced by the tax shield of external debt and the cost of tax grants for internal debt. The latter can differ between financially constrained and financially unconstrained

\footnotetext{
${ }^{18}$ The output price of the good produced by the MNEs is fixed on the world market. Consumer surplus is therefore unchanged throughout our analysis.

${ }^{19}$ We are not interested in the relationship between the host country's statutory tax rate and its thin capitalization rule but between its financial development and its thin capitalization rule. Endogenizing the choice of the tax rate increases the complexity of the analysis without adding additional insights. Indeed, a higher tax rate has a similar effect as a more lenient thin capitalization rule as the tax rate differential increases and therefore the MNE's incentive to give a higher loan to the affiliate. However, it comes along with a negative effect on investment as not all costs of capital are tax-deductible. This makes the statutory tax rate a less attractive instrument to counter the credit market friction.
} 
affiliates. ${ }^{20}$ Both sources of costs depend on the type of thin capitalization rule $z$ the government implements. The tax base in country 1 reads

$$
T_{1}=\int_{\underline{\theta}}^{\bar{\theta}}\left[\theta^{j} f\left(K^{j}\right)-\left(r D_{E}^{j}+\phi^{j}(z)\right)\right] d G\left(\theta^{j}\right) .
$$

The sum of the resident affiliates' profits is given by ${ }^{21}$

$$
\Pi_{1}=\int_{\underline{\theta}}^{\bar{\theta}}\left[\left(1-t_{1}\right) \theta^{j} f\left(K^{j}\right)-r K^{j}+t_{1}\left(r D_{E}^{j}+\phi^{j}(z)\right)\right] d G\left(\theta^{j}\right) .
$$

Using (8) and (9) in (7) yields

$$
W_{1}=\int_{\underline{\theta}}^{\bar{\theta}}\left[\varepsilon+(1-\varepsilon) t_{1}\right] \theta^{j} f\left(K^{j}\right)-(1-\varepsilon) t_{1}\left[r D_{E}^{j}+\phi^{j}(z)\right]-\varepsilon r K^{j} d G\left(\theta^{j}\right) .
$$

Considering the tax rate as given and maximizing welfare with respect to $z$ implicitly determines the optimal thin capitalization rule ${ }^{22}$

$$
\begin{aligned}
\frac{\partial W_{1}}{\partial z} & =\int_{\underline{\theta}}^{\hat{\theta}}\left[\varepsilon+(1-\varepsilon) t_{1}\right] \theta^{j} f^{\prime}\left(K^{j}\right) \frac{\partial D_{I}^{j}}{\partial z}-(1-\varepsilon) t_{1} \frac{\partial \phi^{j}(z)}{\partial z}-\varepsilon r \frac{\partial D_{I}^{j}}{\partial z} d G\left(\theta^{j}\right) \\
& -\int_{\hat{\theta}}^{\bar{\theta}}(1-\varepsilon) t_{1} \frac{\partial \phi^{j}(z)}{\partial z} d G\left(\theta^{j}\right) \leq 0,
\end{aligned}
$$

where $\frac{\partial \phi^{j}(z)}{\partial z}>0$ as a more generous thin capitalization rule increases affiliates' deductibility thresholds. A higher allowance of internal interest deductibility has three effects on country 1's welfare. Firstly, MNEs will allocate more internal loans to their producing affiliate. This alleviates affiliates' financing constraint and allows them to raise further external debt. Financially constrained affiliates then use these extra funds to increase their investment. This increases the tax base. Secondly, a higher internal debt reduces the affiliates' cost of capital which in turn leads to higher profits. However,

\footnotetext{
${ }^{20}$ In principle, concealment costs can be so convex that MNEs refrain from giving additional internal loans, despite the possibility of tax deductibility. In such a case, the government's trade-off no longer exists as a higher allowance for tax deductions is only used by financially constrained affiliates. This ultimately leads to the abolishment of the thin capitalization rule. To exclude this trivial case, we assume that concealment costs are not too convex such that affiliates will always make use of a higher allowance of interest deductibility. The costs for the government are then equivalent to affiliates' thresholds $\phi^{j}(z)$.

${ }^{21} \mathrm{Keep}$ in mind that the costs of concealing internal debt has to be born by the financial center.

${ }^{22}$ Changes in the amount of external finance for financially constrained affiliates are incorporated in the marginal return on investment $\theta^{j} f^{\prime}\left(K^{j}\right)$. Moreover, financially unconstrained affiliates neither change their level of external funds nor their level of investment as their investment is already first-best.
} 
thirdly, a higher deductibility allowance also reduces the tax base and thus tax revenues. The government will therefore only grant a positive amount of internal interest deductibility if the gains from the additional investment of financially constrained affiliates and the increase in the affiliates' profits are higher than the tax losses of merely profit shifting, financially unconstrained affiliates.

Let us consider the two extreme cases of the welfare function. If $\varepsilon=0$, the government just maximizes tax revenues. The optimal thin capitalization rule for a Leviathan government is given by

$$
\left.\frac{\partial W_{1}}{\partial z}\right|_{\varepsilon=0}=t_{1} \int_{\underline{\theta}}^{\hat{\theta}} \theta^{j} f^{\prime}\left(K^{j}\right) \frac{\partial D_{I}^{j}}{\partial z}-\frac{\partial \phi^{j}(z)}{\partial z} d G\left(\theta^{j}\right)-t_{1} \int_{\hat{\theta}}^{\bar{\theta}} \frac{\partial \phi^{j}(z)}{\partial z} d G\left(\theta^{j}\right) \leq 0 .
$$

The government will only grant a positive deductibility if the increase in investment of financially constrained affiliates is large enough to cover the costs that arise due to more profit shifting by the financially unconstrained affiliates. Note, however, that the government might have no incentive to allow any deduction for internal interest payments even if financially constrained affiliates increase their investment. This is true if the average marginal return on capital of the financially constrained affiliates is lower than the costs of a more generous rule $-t_{1} r$. In this case, the tax revenue gain from financially constrained affiliates would, on average, also be negative.

If $\varepsilon=1$, the profits of affiliates are as important to the government as are tax revenues. In this case, the optimal thin capitalization rule is determined by

$$
\left.\frac{\partial W_{1}}{\partial z}\right|_{\varepsilon=1}=\int_{\underline{\theta}}^{\hat{\theta}}\left[\theta^{j} f^{\prime}\left(K^{j}\right)-r\right] \frac{\partial D_{I}^{j}}{\partial z} d G\left(\theta^{j}\right)>0
$$

which is always positive. This means that the government sets the thin capitalization rule in such a way that financially constrained affiliates reach first-best investment at the margin. Hence, there is no reason for the government to implement a binding thin capitalization rule. Obviously, the government grants a higher deductibility allowance when $\varepsilon=1$ than when $\varepsilon=0$. The reason is that the tax base deduction is just a redistribution from the government to the affiliates. The higher $\varepsilon$, the lower the reduction in welfare per unit redistributed. The negative effect completely vanishes for $\varepsilon=1$. We can summarize our findings as follows:

Proposition 1 If the financial development of the host country is sufficiently low, the optimal thin capitalization rule allows positive internal interest deductions. Moreover, the higher the weight of affiliates' profits in the welfare function, the higher the deduction granted by the government. 
Proposition 1 highlights a simple, yet previously neglected motive why governments set lenient thin capitalization rules. In the presence of financial frictions governments are willing to set a more generous thin capitalization rule. This increases profit shifting by financially unconstrained affiliates. However it also reduces the cost of capital for financially constrained affiliates and alleviates their financing constraint. Consequently, investment of constrained affiliates increases and can overcompensate the negative effect of the financially constrained ones.

This leads to the interesting question of how the host country's financial development affects the strictness of the thin capitalization rule. To answer this question, we apply the implicit function theorem on the first-order condition in (11) and get

$$
\frac{\partial z}{\partial \lambda}=-\frac{\partial^{2} W_{1} /(\partial \lambda \partial z)}{S O C_{\lambda}}
$$

where $S O C_{\lambda}<0$ is the second order condition for $\lambda$. What remains to be determined is the sign of the numerator which will also determine the sign of equation (14). To determine the sign of the numerator, we differentiate (11) with respect to $\lambda$ and get

$$
\begin{aligned}
\frac{\partial^{2} W_{1}}{\partial z \partial \lambda} & =\int_{\underline{\theta}}^{\hat{\theta}}\left[\varepsilon+(1-\varepsilon) t_{1}\right] \theta^{j} f^{\prime \prime}\left(K^{j}\right) \frac{\partial K^{j}}{\partial \lambda} \frac{\partial D_{I}^{j}}{\partial z} d G\left(\theta^{j}\right) \\
& -\left[\varepsilon+(1-\varepsilon) t_{1}\right] \hat{\theta} f^{\prime}(\hat{K}) \frac{\partial \hat{D}_{I}}{\partial z} \frac{\partial \hat{\theta}}{\partial \lambda} g(\hat{\theta})<0,
\end{aligned}
$$

where $\frac{\partial K^{j}}{\partial \lambda}>0$ and $\frac{\partial \hat{\theta}}{\partial \lambda}<0$ as the marginal affiliate which is financially unconstrained has a lower productivity when affiliates can raise more external funds. As the sign of (15) is unambiguously negative, we can conclude that a higher financial development reduces the optimal allowance for internal interest payments. We summarize our findings as follows:

Proposition 2 The optimal allowance for internal interest payments $z$ decreases when the financial development of the host country $\lambda$ increases.

The reason for this is twofold as there is an adjustment of both the internal and the external margin. First, a better financial development allows affiliates to raise more external funds. This increases the level of investment of all financially constrained affiliates. As a consequence, a more generous thin capitalization rule has a smaller effect on the expansion of financially constrained affiliates' investments (first term on the right-hand side of (15)). Second, affiliates that are slightly financially constrained 
become financially unconstrained when the financial development improves. A higher allowance of internal interest payments then has no effect on their level of investment (second term on the right-hand side of $(15)){ }^{23}$

\section{Safe haven rule vs. earnings stripping rule}

Our analysis in the previous section has shown that the implementation of a lenient thin capitalization rule can result from limited access to external funding. In this section, we compare two systems, the safe haven debt-to-equity ratio and the earnings stripping rule and ask which one is preferable. To do this, we first have to highlight the main differences between the two rules.

The safe haven rule disallows the tax deduction of interest payments to related parties if internal debt exceeds a specified debt-to-equity ratio. The permissible amount of internal debt is calculated from the amount of equity within the affiliate, multiplied by the specified debt-to-equity ratio. Moreover, the safe haven rule does not affect MNEs' incentives with respect to the internal interest rate. This means that the safe haven rule only restricts the amount of internal debt.

The earnings stripping rule disallows the tax deduction of interest payments to related parties if internal debt exceeds a certain proportion of the affiliate's earnings before interest, taxes, depreciation and amortization (EBITDA). This rule is based on the affiliate's economic activity. Furthermore, the earnings stripping rule disallows deductibility if the value of internal interest payments, i.e. the amount of internal loans times the internal interest rate, surpasses the affiliate's threshold.

\subsection{The comparison with debt shifting only}

We begin our analysis by first looking at MNEs' profit under the two thin capitalization rules. The overall profit of MNEs under the safe haven rule is

$$
\pi^{j}(\delta)=\left(1-t_{1}\right) \theta^{j} f\left(K^{j}\right)-r K^{j}+t_{1} r D_{E}^{j}+t_{1} \min \left(r D_{I}^{j}, r \delta\right)-t_{2} r D_{I}^{j}-C\left(D_{I}^{j}\right)
$$

\footnotetext{
${ }^{23}$ According to the model, financially advanced countries should have a thin capitalization rule, which is as strict as possible. This is due to our simplifying assumption to abstract from costs of excessive external borrowing and higher risk of bankruptcy, which allows financially unconstrained affiliates to perfectly substitute external for internal debt. See Huizinga et al. (2008) and Møen et al. (2011) for a theoretical and empirical analysis of external debt shifting.
} 
where $\phi^{j}(z)=r \delta$ is the threshold for the tax-deductibility of internal interest payments under the safe haven rule. Given the level of equity, a relaxation of the safe haven rule $\delta$ by one unit allows the affiliate to deduct exactly one unit of internal loans from its tax base.

Under the earnings stripping rule, the overall profit of MNEs is given by

$\pi^{j}(\alpha)=\left(1-t_{1}\right) \theta^{j} f\left(K^{j}\right)-r K^{j}+t_{1} r D_{E}^{j}+t_{1} \min \left(r D_{I}^{j}, \alpha \theta^{j} f\left(K^{j}\right)\right)-t_{2} r D_{I}^{j}-C\left(D_{I}^{j}\right),(17)$

where $\phi^{j}(z)=\alpha \theta^{j} f\left(K^{j}\right)$ depicts the threshold of tax-deductibility of internal interest payments under the earnings stripping rule. Under this rule, the threshold of tax deductibility differs across affiliates. A more generous earnings stripping rule increases affiliates' allowance for tax-deduction by a factor of $\theta^{j} f\left(K^{j}\right)$. More productive affiliates can deduct a higher amount of internal interest payments as compared to less productive ones because they have a higher EBITDA.

In the following, we determine which of the two thin capitalization rules generates the higher welfare. We do this by comparing welfare levels under the safe haven rule and the earnings stripping rule. Under the safe haven rule country welfare amounts to

$$
W(\delta)=\int_{\underline{\theta}}^{\bar{\theta}}\left[\varepsilon+(1-\varepsilon) t_{1}\right] \theta^{j} f\left(K^{j}\right)-(1-\varepsilon) t_{1}\left[r D_{E}^{j}+r \delta\right]-\varepsilon r K^{j} d G\left(\theta^{j}\right) .
$$

As all affiliates have the same stock of equity, the threshold for the deductibility of internal interest payments is the same for affiliates under the safe haven rule. Under the earnings stripping rule welfare is given by

$$
W(\alpha)=\int_{\underline{\theta}}^{\bar{\theta}}\left[\varepsilon+(1-\varepsilon) t_{1}\right] \theta^{j} f\left(K^{j}\right)-(1-\varepsilon) t_{1}\left[r D_{E}^{j}+\alpha \theta^{j} f\left(K^{j}\right)\right]-\varepsilon r K^{j} d G\left(\theta^{j}\right) .
$$

with the difference that the threshold under the earnings stripping rule is firm-specific and depends on the productivity.

We take the difference of (18) and (19) and get

$$
\begin{aligned}
\Delta \equiv W(\delta)-W(\alpha)= \\
\\
\quad \int_{\underline{\theta}}^{\bar{\theta}}\left[\varepsilon+(1-\varepsilon) t_{1}\right] \theta^{j} f\left(K^{j}(\delta)\right)-(1-\varepsilon) t_{1}\left[r D_{E}^{j}(\delta)+r \delta\right]-\varepsilon r K^{j}(\delta) d G\left(\theta^{j}\right) \\
-\quad \int_{\underline{\theta}}^{\bar{\theta}}\left[\varepsilon+(1-\varepsilon) t_{1}\right] \theta^{j} f\left(K^{j}(\alpha)\right)-(1-\varepsilon) t_{1}\left[r D_{E}^{j}(\alpha)+\alpha \theta^{j} f\left(K^{j}(\alpha)\right)\right]-\varepsilon r K^{j}(\alpha) d G\left(\theta^{j}\right)
\end{aligned}
$$


To compare these two thin capitalization rules, we assume a government with a welfare maximizing earnings stripping rule $\alpha^{*} \theta^{j} f\left(K^{j}\right)$. We then ask whether a safe haven rule that generates a higher welfare than the optimal earnings stripping rule exists. To answer this question, we assume a safe haven rule $\delta^{\alpha}$ so that

$$
r \delta^{\alpha}=\alpha^{*} \tilde{\theta} f(\tilde{K}),
$$

where the affiliate with a productivity of $\tilde{\theta}$ has the same tax deductions under both systems and is thus indifferent to either of the two thin capitalization rules. We then set this affiliate's productivity at a level which makes its contribution to welfare zero. ${ }^{24}$ All affiliates with a productivity lower than $\tilde{\theta}$ positively contribute to the country's welfare, whereas affiliates with a productivity higher than $\tilde{\theta}$ negatively contribute to welfare. The difference in welfare is given by

$$
\begin{aligned}
& \Delta\left(\delta^{\alpha}, \alpha^{*}\right)= \\
= & \int_{\underline{\theta}}^{\tilde{\theta}}\left[\varepsilon+(1-\varepsilon) t_{1}\right] \theta^{j} f\left(K^{j}\left(\delta^{\alpha}\right)\right)-(1-\varepsilon) t_{1}\left[r D_{E}^{j}\left(\delta^{\alpha}\right)+r \delta^{\alpha}\right]-\varepsilon r K^{j}\left(\delta^{\alpha}\right) d G\left(\theta^{j}\right) \\
- & \int_{\underline{\theta}}^{\tilde{\theta}}\left[\varepsilon+(1-\varepsilon) t_{1}\right] \theta^{j} f\left(K^{j}\left(\alpha^{*}\right)\right)-(1-\varepsilon) t_{1}\left[r D_{E}^{j}\left(\alpha^{*}\right)+\alpha^{*} \theta^{j} f\left(K^{j}\left(\alpha^{*}\right)\right)\right]-\varepsilon r K^{j}\left(\alpha^{*}\right) d G\left(\theta^{j}\right) \\
+ & \int_{\tilde{\theta}}^{\hat{\theta}}\left[\varepsilon+(1-\varepsilon) t_{1}\right] \theta^{j} f\left(K^{j}\left(\delta^{\alpha}\right)\right)-(1-\varepsilon) t_{1}\left[r D_{E}^{j}\left(\delta^{\alpha}\right)+r \delta^{\alpha}\right]-\varepsilon r K^{j}\left(\delta^{\alpha}\right) d G\left(\theta^{j}\right) \\
- & \int_{\tilde{\theta}}^{\hat{\theta}}\left[\varepsilon+(1-\varepsilon) t_{1}\right] \theta^{j} f\left(K^{j}\left(\alpha^{*}\right)\right)-(1-\varepsilon) t_{1}\left[r D_{E}^{j}\left(\alpha^{*}\right)+\alpha^{*} \theta^{j} f\left(K^{j}\left(\alpha^{*}\right)\right)\right]-\varepsilon r K^{j}\left(\alpha^{*}\right) d G\left(\theta^{j}\right) \\
+ & \int_{\hat{\theta}}^{\bar{\theta}}(1-\varepsilon) t_{1} r\left[\alpha^{*} \theta^{j} f\left(K^{j}\left(\alpha^{*}\right)\right)-r \delta^{\alpha}\right] d G\left(\theta^{j}\right)
\end{aligned}
$$

By using (21), we are able to decompose the difference in welfare into three components. ${ }^{25}$ The first two terms of (22) comprise affiliates with a productivity between $\underline{\theta}$ and $\tilde{\theta}$. These affiliates are financially constrained and can deduct a higher amount under the safe haven rule as defined in (21) than under the optimal earnings stripping rule. This means that under a safe haven rule the investment level of these affiliates is higher so that the net effect of the two terms is positive. The third and the fourth term of (22) again consider the welfare of financially constrained affiliates. However,

\footnotetext{
${ }^{24}$ For a Leviathan government the level of $\tilde{\theta}$ is determined by a zero contribution to tax revenues. The higher the weight on affiliates' profits, the higher is $\tilde{\theta}$ as the loss in tax revenues is compensated by higher affiliates' profits.

${ }^{25}$ Note that $\tilde{\theta}$ must be smaller than $\hat{\theta}$. Inspecting the term in the second line of the first-order condition (11), we see that the effect of unconstrained affiliates on welfare is negative as long as $\varepsilon<1$.
} 
these affiliates' contribution to welfare is negative as their productivity is greater than $\tilde{\theta}$. Consequently, a lower allowance of tax deductions renders a higher welfare. Thus, welfare under the safe haven rule $\delta^{\alpha}$ must be higher than under the optimal earnings stripping rule, i.e. the net effect of the third and the fourth term is positive. The fifth term includes financially unconstrained affiliates. Independent of the thin capitalization rule, financially unconstrained affiliates have the same amount of external debt and the same level of investment. Thus, what matters for welfare is just the effect on tax revenues. For these affiliates, the safe haven rule $\delta^{\alpha}$ permits fewer tax deductions as compared to the optimal earnings stripping rule. Consequently, tax revenues are higher under the safe haven rule $\delta^{\alpha}$.

Our intuition is the following: under an earnings stripping rule financially unconstrained affiliates and slightly financially constrained affiliates whose contribution to welfare is negative have a higher allowance for tax deductions as compared to under a safe haven rule. These affiliates use the more generous tax deductions under an earnings stripping rule to shift profits to the low tax country without considerably changing their level of investment and therefore have a smaller tax base. Moreover, heavily constrained affiliates whose contribution to welfare is positive have a lower threshold under an earnings stripping rule. Investment levels are therefore smaller and, as a consequence, so is their tax base. We summarize our findings as follows:

Proposition 3 If firms are not able to manipulate transfer prices, welfare is higher under a safe haven rule than under an earnings stripping rule.

This finding can be linked to the current practice of internal interest deductibility. Looking at countries' thin capitalization rules, we see that the majority of them has implemented a safe haven debt-to-equity ratio. ${ }^{26}$ One reason for this practice can be related to the fact that an earnings stripping rule gives financially unconstrained firms more leeway to engage in debt shifting. A safe haven rule limits this possibility and additionally gives financially constrained firms a better opportunity to expand their investment. Another reason could be that a safe haven rule tends to be associated with lower administrative costs than an earnings stripping rule. Under a safe haven rule there is one specified threshold for internal interest payments which applies to all firms. Under an earnings stripping rule the threshold for internal interest payments has to be calculated for each firm separately based on their EBITDA.

\footnotetext{
${ }^{26}$ Only seven countries apply a pure earnings stripping rule. These countries are Finland, Germany, Italy, Japan, Norway, Portugal and Spain.
} 


\subsection{The comparison with debt shifting and transfer price ma- nipulation}

In our baseline model, MNEs are able to shift profits into the tax haven by deciding upon the quantity of internal loans, while sticking to the arm's-length price. However, MNEs might also shift profits via the manipulation of the internal interest rate paid to the financial center. In this way, MNEs have two channels to engage in profit-shifting. A quantity channel, i.e. the amount of internal loans, and a price channel by charging a higher internal interest rate $r_{P}^{j}>r$. We assume that the MNE incurs convex costs when manipulating the transfer price and that costs of debt shifting and transfer price manipulation are separable so that $C^{j}\left(D_{I}^{j}, r_{P}^{j}\right)=C_{D}\left(D_{I}^{j}\right)+C_{r}\left(r_{P}^{j}\right) .{ }^{27}$ With transfer price manipulation, taxable profits of the producing affiliate and total profits of the financial center, respectively, change to

$$
\begin{aligned}
\rho_{1}^{j t} & =\theta^{j} f\left(K^{j}\right)-r D_{E}^{j}-\min \left(r_{P}^{j} D_{I}^{j}, \phi^{j}(z)\right), \\
\rho_{2}^{j} & =-t_{2} r_{P}^{j} D_{I}^{j}-C^{j} .
\end{aligned}
$$

Using (2), (23) and (24), MNEs' overall profits can be written as

$$
\pi^{j}=\left(1-t_{1}\right) \theta^{j} f\left(K^{j}\right)-r K^{j}+t_{1} r D_{E}^{j}+t_{1} \min \left(r_{P}^{j} D_{I}^{j}, \phi^{j}(z)\right)-t_{2} r_{P}^{j} D_{I}^{j}-C^{j}
$$

As in the baseline model, each MNE chooses the profit maximizing amount of internal loans. Additionally, the MNE can also shift profits via interest rate manipulation. The first-order conditions both for $D_{I}^{j}$ and $r_{P}^{j}$ in the case of a financially constrained affiliate are given by

$$
\begin{aligned}
\left(1-t_{1}\right) \theta^{j} f^{\prime}\left(K^{j}\right)-r+\left(\mu t_{1}-t_{2}\right) r_{P}^{j}-C_{D}^{\prime}\left(D_{I}^{j}\right) & \leq 0 \\
\left(\mu t_{1}-t_{2}\right) D_{I}^{j}-C_{r}^{\prime}\left(r_{P}^{j}\right) & \leq 0
\end{aligned}
$$

From (26) and (27) we see that the possibility of transfer price manipulation also has an indirect, positive effect on investment. The reason is that a higher internal interest rate makes debt shifting more attractive. This increases the amount of internal loans to financially constrained affiliates which in turn promotes production. For financially unconstrained affiliates there is no positive effect on production and therefore the incentive to use internal loans is comparably smaller.

${ }^{27}$ Government actions against profits shifting when costs of debt shifting and transfer price manipulation are interrelated are analyzed by Schindler and Schjelderup (2013). 
Does the possibility of internal interest rate manipulation change the results in section 4.1? To answer this question, we have to recall that the main difference between the two thin capitalizations rules is that the safe haven rule does not affect MNEs' incentives with respect to the internal interest rate $r_{P}^{j}$. For MNEs this means that under a safe haven rule, the first-order condition for transfer prices (27) always holds with equality. In contrast, under a binding earnings stripping rule, the profit maximizing MNE equates the marginal gain from internal debt with the marginal gain from a higher transfer price. Hence, a binding earnings stripping rule affects both the amount of internal loans and the internal interest rate.

In order to compare the two rules under transfer price manipulation, we assume a government with a welfare maximizing safe haven rule $\delta^{*}$ and an earnings stripping rule $\alpha^{\delta}$ so that

$$
\alpha^{\delta} \bar{\theta} f(\bar{K})=\bar{r}_{P}\left(\delta^{*}\right) \delta^{*}
$$

which means that the affiliate with the highest productivity $\bar{\theta}$ has the same tax deductions under both thin capitalization rules. All affiliates with a productivity lower than $\bar{\theta}$ have a lower threshold for tax deductions under the earnings stripping rule. We again examine the difference in welfare levels which is given by

$$
\begin{aligned}
& \Delta_{P}\left(\delta^{*}, \alpha^{\delta}\right)= \\
= & \int_{\underline{\theta}}^{\hat{\theta}}\left[\varepsilon+(1-\varepsilon) t_{1}\right] \theta^{j} f\left(K^{j}\left(\delta^{*}\right)\right)-(1-\varepsilon) t_{1}\left[r D_{E}^{j}\left(\delta^{*}\right)+r_{P}^{j} \delta^{*}\right]-\varepsilon r K^{j}\left(\delta^{*}\right) d G\left(\theta^{j}\right) \\
- & \int_{\underline{\theta}}^{\hat{\theta}}\left[\varepsilon+(1-\varepsilon) t_{1}\right] \theta^{j} f\left(K^{j}\left(\alpha^{\delta}\right)\right)-(1-\varepsilon) t_{1}\left[r D_{E}^{j}\left(\alpha^{\delta}\right)+\alpha^{\delta} \theta^{j} f\left(K^{j}\left(\alpha^{\delta}\right)\right)\right]-\varepsilon r K^{j}\left(\alpha^{\delta}\right) d G\left(\theta^{j}\right) \\
- & \int_{\hat{\theta}}^{\bar{\theta}}(1-\varepsilon) t_{1}\left[r_{P}^{j} \delta^{*}-\alpha^{\delta} \theta^{j} f\left(K^{j}\left(\alpha^{\delta}\right)\right)\right] d G\left(\theta^{j}\right) .
\end{aligned}
$$

The sign of (29) is ambiguous because there are two countervailing effects. Welfare is higher under a safe haven rule because financially constrained affiliates have higher tax deductions and thus a higher level of investment (first two integrals). However, under an earnings stripping rule, profit shifting of MNEs with a financially unconstrained affiliate can be tackled more effectively because the value of internal interest payments which can be deducted from the tax base is smaller (third integral).

In a next step we ask now under which circumstances an earnings stripping rule dominates the safe haven rule. First, if the negative effect of a tightening of any thin capitalization rule on the investment of financially constrained affiliates is small, then the first two terms on the right-hand side of (29) are negligible. Second, as long as $\varepsilon<1$, 
the third term on the right-hand side of (29) is smaller than zero. Thus, an earnings stripping rule dominates if financing constraints are not too severe and tax revenues are more important than affiliates' profits. We summarize our findings as follows:

Proposition 4 In the case where firms are able to manipulate transfer prices, welfare under an earnings stripping rule is higher as compared to under a safe haven rule if the host country's financial development is sufficiently high and tax revenues are more important than affiliates profits.

The model can explain the recent practice of some countries to switch from a safe haven rule to an earnings stripping rule. These countries (Finland, Germany, Italy, Japan, Norway, Portugal and Spain) are all financially advanced countries. Hence, the presence of a tight thin capitalization rule, leads to only small negative investment effects. Moreover, if most of countries' capital is invested through financial intermediaries, such as pension funds or insurance companies, residents of each country invest their capital at least to some extent in diversified global portfolios. Hence, ownership of local firms is not solely in the hand of a country's residents which is a reason why tax revenues could be more important to governments. It seems like, for the above mentioned countries, the benefit of a switch is still higher despite potentially higher administrative costs of the earnings stripping rule. ${ }^{28}$

\section{Discussion}

In this section we broaden the scope of the model and discuss two issues which ensue from our analysis. In Section 5.1 we consider the impact of firm heterogeneity on the results of our comparison in Section 4. In Section 5.2 we revisit the effects of a binding thin capitalization rule on the relation of internal and external debt.

\subsection{The impact of firm heterogeneity}

One question which immediately arises from the analysis in Section 4 is how firm heterogeneity affects our results of the welfare comparisons in Sections 4.1 and 4.2. We

\footnotetext{
${ }^{28}$ In our model we abstract from transfer price regulations. However, the results of Proposition 4 will only change if transfer price regulations are perfectly binding. Then Proposition 3 steps in as $r_{P}^{j}=r, \forall j$. Thus, whenever MNEs have the opportunity to circumvent transfer price regulations a switch to an earnings stripping rule can be welfare improving.
} 
tackle this issue by marginally expanding the range of productivity on both ends of the support and will then again compare welfare levels under both rules.

For the case in which firms are not able to manipulate transfer prices, we apply Leibniz's rule on equation (22) and get

$$
\begin{aligned}
\Delta^{\text {het }} & =\Delta\left(\delta^{\alpha}, \alpha^{*}\right)+ \\
+ & {\left[\varepsilon+(1-\varepsilon) t_{1}\right] \underline{\theta} f\left(\underline{K}\left(\delta^{\alpha}\right)\right)-(1-\varepsilon) t_{1}\left[r \underline{D}_{E}\left(\delta^{\alpha}\right)+r \delta^{\alpha}\right]-\varepsilon r \underline{K}\left(\delta^{\alpha}\right) g(\underline{\theta}) } \\
-\quad & {\left[\varepsilon+(1-\varepsilon) t_{1}\right] \underline{\theta} f\left(\underline{K}\left(\alpha^{*}\right)\right)-(1-\varepsilon) t_{1}\left[r \underline{D_{E}}\left(\alpha^{*}\right)+\alpha^{*} \underline{\theta} f\left(\underline{K}\left(\alpha^{*}\right)\right)\right]-\varepsilon r \underline{K}\left(\alpha^{*}\right) g(\underline{\theta}) } \\
+\quad & (1-\varepsilon) t_{1} r\left[\alpha^{*} \bar{\theta} f\left(\bar{K}\left(\alpha^{*}\right)\right)-r \delta^{\alpha}\right] g(\bar{\theta}),
\end{aligned}
$$

where we know from the discussion of (22) that the net effect of the second and the third term as well as the fourth term on the right-hand side of (30) must be positive as $\bar{\theta}>\tilde{\theta}>\underline{\theta}$. Hence, the overall effect is unambiguously positive which means that the benefit of a safe haven rule increases with the degree of firm heterogeneity. The reason for this is based on the same argument as made in proposition 3. An earnings stripping rule favors/discriminates financially unconstrained/constrained affiliates as compared to a safe haven rule. An increase in the degree of firms heterogeneity just reinforces this contrast by increasing the number of financially unconstrained/constrained affiliates which can deduct more/less under an earnings stripping rule.

We can do the same exercise in the case where firms have the opportunity to manipulate the interest rate for internal loans. Again, we apply Leibniz's rule on the difference in welfare levels as given in (29) which yields

$$
\begin{aligned}
& \Delta_{P}^{h e t}=\Delta_{P}\left(\delta^{*}, \alpha^{\delta}\right) \\
- & {\left[\varepsilon+(1-\varepsilon) t_{1}\right] \underline{\theta} f\left(\underline{K}\left(\alpha^{\delta}\right)\right)-(1-\varepsilon) t_{1}\left[r \underline{D}_{E}\left(\alpha^{\delta}\right)+\alpha^{\delta} \underline{\theta} f\left(\underline{K}\left(\alpha^{\delta}\right)\right)\right]-\varepsilon r \underline{K}\left(\alpha^{\delta}\right) g(\underline{\theta}) } \\
+ & {\left[\varepsilon+(1-\varepsilon) t_{1}\right] \underline{\theta} f\left(\underline{K}\left(\delta^{*}\right)\right)-(1-\varepsilon) t_{1}\left[r \underline{D}_{E}\left(\delta^{*}\right)+r_{P}^{j} \delta^{*}\right]-\varepsilon r \underline{K}\left(\delta^{*}\right) g(\underline{\theta}), }
\end{aligned}
$$

where the net effect of the second and the third term on the right-hand side of (31) is positive as affiliates with productivity $\underline{\theta}$ have higher tax deductions under a safe haven rule. As before the underlying reason is that higher deductions by financially constrained affiliates increase their level of investment which renders a higher welfare. Thus, the benefit of a safe haven rule increases also in the case of transfer price manipulation if the degree of firm heterogeneity increases. 


\subsection{The relation of internal and external debt}

In this section, we briefly discuss the effect of a change in the tightness of the thin capitalization rule on the relation between internal and external debt. Existing empirical studies which analyze the effectiveness of limiting the tax deductibility of internal interest payments typically find that internal and external debt are substitutes. Blouin et al. (2014), Büttner et al. (2012) and Wamser (2014) find that a tightening of the thin capitalization rule reduced internal debt-to-asset ratios at a larger scale as compared to total debt-to-asset ratios. The reason for this is that firms substitute external debt for internal debt. This substitution gives firms the opportunity to avoid additional taxation under a binding thin capitalization rule as interest expenses on external debt is always tax-deductible.

The effect seems reasonable if firms are in a position to substitute between these two types of finance. That is, either firms are located in a financially advanced country in which the provision of external funds is easy or firms have enough collateral to raise sufficient external funds despite being located in a financially less developed country. Hence, only if either of the two cases can be applied the substitution of external for internal debt is a feasible strategy.

In our model, firms are able to perfectly substitute external for internal debt if investment is not constricted by the credit market friction. Indeed, this is the case if the financial constraint given in equation (1), which restricts the amount of external funds firms are able to raise, is not binding. Accordingly, only financially unconstrained firms are able to follow the strategy to substitute between the two types of debt. As a result, a tightening of the thin capitalization rule has no effect on total indebtedness of financially unconstrained firms. This, of course, is due to our simplifying assumption to abstract from any cost of financial distress related to the amount of external debt within the MNE. Accounting for such costs would reduce the total debt-to-asset ratio due to a tightening of the thin capitalization rule as it is typically found in the empirical literature.

However, this relation does not need to hold for firms which are financially constrained. For them external funds are scarce, meaning that the total amount that they can raise will be used for their production. The credit market restriction in (1) tells us that a stricter thin capitalization rule hits financially constrained firms twice as hard. First, it directly reduces the amount of internal debt and therefore firms' own resources. Second, 
it indirectly reduces external debt as a reaction to the cut in own resources. In contrast to financially unconstrained firms, the effect of a stricter thin capitalization rule on the total debt of financially constrained firms is more pronounced than the effect on internal debt because the reduction in internal debt is accompanied by a reduction in external debt. The reason is that, for financially constrained firms, the two sources of finance are complements.

Moreover, we can examine how an improvement of the financial development affects the magnitude of the reduction in firms' total debt-to-asset ratio due to a tightening in the thin capitalization rule. For the very same reasons mentioned before, an improvement in the financial development has no effect on the total indebtedness of financially unconstrained firms as internal debt is perfectly substituted for external debt. To understand the underlying effect on financially constrained firms, it is again helpful to examine (1). As the credit multiplier $\lambda$ is higher in a financially more advanced country, a tighter thin capitalization rule reduces the amount of external funds by more if firms reduce internal loans as a reaction to the reduction in tax deductions. In other words, the reduction of a financially constrained firm's internal debt causes a greater reduction in external debt and therefore a greater reduction in total indebtedness if the financially constrained firm is located in a country which is financially more developed. This is the case as long as the firm is still constrained when the financial development improves. ${ }^{29}$

\section{Conclusion}

This paper has introduced a model in which a high-tax country chooses its optimal thin capitalization rule in the presence of financial frictions. The key element of the model is a financing constraint, which we relate to the financial development of the host country which restricts external fund-raising of some MNEs. The result of a weak financial development is that low-productivity MNEs cannot exploit all investment opportunities due to the lack of finance. This effect is stronger, the weaker the host country's financial development.

In this paper, we first show that host countries grant some tax deductions for internal interest payments when less productive firms are financially very constrained. with the

\footnotetext{
${ }^{29}$ The aggregate effect might still be greater in a financially less developed country as there are more financially constrained firms.
} 
effect that these firms are indirectly assisted in raising more external funds which, in turn, increases their tax base. Moreover, the optimal amount of tax deductions increases when the financial development of the host country worsens as the financial situation of financially constrained firms also worsens. Indeed, this is consistent with countries' tax policy as shown in table 1. Thus, the model offers an explanation for why countries differ in the strictness of their thin capitalization rules besides beggar-thy-neighbor policies on which the literature has focused so far.

We then ask, given that the host country implements a binding thin capitalization rule, which one of the two most common types should be put into effect in order to maximize the host country's welfare: the safe haven rule, which allows to deduct internal interest payments as long as a specified debt-to-equity ratio is not exceeded, or the earnings stripping rule, which permits deductibility if the amount does not surpass a certain fraction of the affiliate's EBITDA. We show that, under a safe haven rule welfare is higher when firms cannot engage in transfer price manipulation. This is due to the fact that the earnings stripping rule favors/discriminates financially unconstrained/constrained firms more as compared to the safe haven rule. However, when firms can engage in transfer price manipulation, welfare under an earnings stripping rule can be higher if tax revenues are important for the government and the host country's financial development is sufficiently high. The reason for this is that a safe haven rule only restricts the amount of internal debt whereas the earnings stripping rule restricts the value. The model therefore provides an answer to why countries differ in types of thin capitalization rules.

Our model can be extended in several ways. First, it abstracts from uncertainty. In a framework in which demand is volatile, allowance for tax deductions under an earnings stripping rule is also volatile as firms' earnings fluctuate. In economic downturns, in the extreme case of a complete shortfall in demand, an earnings stripping rule will disallow any tax deductions for internal interest payments irrespective of firms' level of internal debt. However, non-deducted interest payments can be forwarded and deducted from future profits. In contrast, a safe haven rule will always allow tax deductions up to the specified threshold. An internal interest carry-forward, however, is not possible. Second, the model can be incorporated in a tax competition framework. Different types of thin capitalization rules can have diverse effects on the competition for mobile firms. As the earnings stripping rule discriminates between different types of firms, their tax rate sensitivity could also be affected differently. It is therefore a priori not 
clear how the degree of tax competition is affected if countries can choose the type of thin capitalization rule. We leave these issues for future research. 


\section{A Deriving the threshold for $\lambda$}

Whether the more or the less productive affiliates suffer more from a weak financial development is a priori ambiguous because there are two opposing effects of a higher productivity. First, a higher productivity increases the marginal return on capital which makes an affiliate financially more constrained for a given amount of capital. Second, HQs have a bigger incentive to allocate internal loans to their producing affiliate because of the higher return on capital which brings down the marginal return on capital also because more external funds can be raised. If a higher productivity leads to a fall in the marginal return on capital, which means that the second negative term dominates the positive first effect, the gap between actual level of investment and first-best level of investment gets smaller the higher an affiliate's productivity. This means that the higher the productivity, the less financially constrained an affiliate. For this to be true, it must be that

$$
\frac{\partial\left(\theta^{j} f^{\prime}\left(K^{j}\right)\right)}{\partial \theta^{j}}=f^{\prime}\left(K^{j}\right)+\theta^{j} f^{\prime \prime}\left(K^{j}\right)\left[\frac{d K^{j}}{d D_{E}^{j}} \frac{d D_{E}^{j}}{d D_{I}^{j}}+\frac{d K^{j}}{d D_{I}^{j}}\right] \frac{d D_{I}^{j}}{d \theta^{j}}<0,
$$

where the first term on the right-hand side of (A.1) is the positive effect on the marginal return to capital whereas the second term displays the negative effect due to an increase in internal as well as external loans. Using (1) and rearranging terms yields

$$
1+\lambda>-\frac{f^{\prime}\left(K^{j}\right)}{\theta^{j} f^{\prime \prime}\left(K^{j}\right) \frac{d D_{I}^{j}}{d \theta^{j}}}
$$

What remains to be determined is the effect of a higher productivity on the amount of internal loans $\frac{d D_{I}^{j}}{d \theta^{j}}$. Totally differentiating (6) with respect to $D_{I}^{j}$ and $\theta^{j}$ gives

$$
\frac{d D_{I}^{j}}{d \theta^{j}}=\frac{\left(1-t_{1}\right) f^{\prime}\left(K^{j}\right)}{C^{\prime \prime}\left(D_{I}^{j}\right)-\left(1-t_{1}\right) \theta^{j} f^{\prime \prime}\left(K^{j}\right)}
$$

Inserting (A.2) in (A.3) and again rearranging terms gives

$$
\lambda^{j}>-\frac{C^{\prime \prime}\left(D_{I}^{j}\right)}{\left(1-t_{1}\right) \theta^{j} f^{\prime \prime}\left(K^{j}\right)} .
$$

In (A.4) we get an affiliate-specific threshold for $\lambda^{j}$ which tells us that an affiliate will be less constrained due to an increase in productivity if the host country's financial development is greater than the affiliate-specific threshold. However, for equation (A.1) to hold generally, we need to identify for which affiliates the threshold given in (A.4) 
is the most demanding. To do this, we derive $\lambda^{j}$ with respect to $\theta^{j}$ which yields

$$
\begin{aligned}
\frac{\partial \lambda^{j}}{\partial \theta^{j}} & =-\frac{\left(1-t_{1}\right) \theta^{j} f^{\prime \prime}\left(K^{j}\right) C^{\prime \prime \prime} \frac{d D_{I}^{j}}{d \theta^{j}}}{\left[\left(1-t_{1}\right) \theta^{j} f^{\prime \prime}\left(K^{j}\right)\right]^{2}} \\
& +\frac{C^{\prime \prime}\left(D_{I}^{j}\right)\left[\left(1-t_{1}\right) f^{\prime \prime}\left(K^{j}\right)+\left(1-t_{1}\right) \theta^{j} f^{\prime \prime \prime}\left(K^{j}\right) \frac{d K^{j}}{d \theta^{j}}\right]}{\left[\left(1-t_{1}\right) \theta^{j} f^{\prime \prime}\left(K^{j}\right)\right]^{2}} .
\end{aligned}
$$

As long as $C^{\prime \prime \prime}\left(D_{I}^{j}\right) \leq 0$ and $f^{\prime \prime \prime}\left(K^{j}\right)$ is not too large if positive, the threshold for $\lambda^{j}$ declines if $\theta^{j}$ increases. This means that the threshold is most demanding for the lowest value of $\theta^{j}$. Hence, the critical value for $\lambda$ is defined by

$$
\lambda>-\frac{C^{\prime \prime}(\underline{D})}{\left(1-t_{1}\right) \underline{\theta} f^{\prime \prime}(\underline{K})}>0,
$$

where the lower bar indicates values for the affiliate with the lowest level of productivity $\underline{\theta}$. 


\section{References}

Aghion P., P. Bacchetta and A. Banerjee (1999). Capital Markets and the Instability of Open Economies. In: Agénor P.R., M. Miller, D. Vines and A. Weber (Eds.), The Asian Financial Crises: Causes, Contagion and Consequences. Cambridge University Press, Cambridge, 167-190.

Aghion P., P. Bacchetta and A. Banerjee (2004). Financial development and the instability of open economies. Journal of Monetary Economics 51, 1077-1106.

Arezki R. and M. Brückner (2012). Rainfall, financial development, and remittances: Evidence from Sub-Saharan Africa. Journal of International Economics 87, 377385 .

Beck T., A. Demirgüç-Kunt, L. Laeven and R. Levine (2008). Finance, firm size and growth, Journal of Money, Credit and Banking 40, 1379-405.

Beck T., R. Levine and N. Loayza (2000). Finance and the sources of growth. Journal of Financial Economics 58, 261-300.

Becker J. and C. Fuest (2010). Taxing foreign profits with international mergers and acquisitions. International Economic Review 51, 171-186.

Bernanke B. and M. Gertler (1989). Agency costs, net worth, and business fluctuations. American Economic Review 79, 14-31.

Blouin J., H. Huizinga, L. Laeven and G. Nicodème (2014). Thin capitalization rules and multinational firm capital structure. CESifo Working Paper No. 4695.

Bond R.S. (2000). Levelling up or levelling down? Some reflections on the ACE and CBIT proposals, and the future of the corporate tax base. In: Cnossen S. (Ed.), Taxing capital income in the European Union. Issues and options for reform. Oxford University, 161-179.

Brown M., S. Ongena, A. Popov and P. Yeşin (2011). Who needs credit and who gets credit in Eastern Europe? Economic Policy 26, 93-130.

Büttner T., M. Overesch, U. Schreiber and G. Wamser (2009). Taxation and capital structure choice - evidence from a panel of German multinationals. Economics Letters 105, 309-311. 
Büttner T., M. Overesch, U. Schreiber and G. Wamser (2012). The impact of thincapitalization rules on the capital structure of multinational firms. Journal of Public Economics 96, 930-938.

Buslei H. and M. Simmler (2012). The impact of introducing an interest barrier evidence from the German corporation tax reform 2008. DIW Discussion Papers 1215.

Chinn M., D.B. Eichengreen and H. Ito (2014). A forensic analysis of global imbalances. Oxford Economic Papers 66, 465-490.

Desai M.A., C.F. Foley and J.R. Hines (2004). A multinational perspective on capital structure choice and internal capital markets. Journal of Finance 59, 2451-2487.

Demirgüç-Kunt A. and V. Maksimovic (1998). Law, Finance, and Firm Growth. Journal of Finance 53. 2107-2137.

Detragiache E., T. Tressel and P. Gupta (2008). Foreign banks in poor countries: theory and evidence. Journal of Finance 63, 2123-2160.

Dourado A. and R. de la Feria (2008). Thin capitalization rules in the context of the CCCTB. Oxford University Centre for Business Taxation, WP08/04.

Dreßler D. and U. Scheuering (2012). Empirical evaluation of interest barrier effects. ZEW Discussion Paper No. 12-046.

Egger P., W. Eggert, C. Keuschnigg and H. Winner (2010). Corporate taxation, debt financing and foreign-plant ownership. European Economic Review 54, 96-107.

Egger P., C. Keuschnigg, V. Merlo and G. Wamser (2014). Corporate taxes and internal borrowing within multinational firms. American Economic Journal: Economic Policy 6, 54-93.

Evans D.S. and B. Jovanovic (1989). An Estimated Model of Entrepreneurial Choice under Liquidity Constraints. Journal of Political Economy 97, 808-827.

Fuest C. and T. Hemmelgarn (2005). Corporate tax policy, foreign firm ownership and thin capitalization. Regional Science and Urban Economics 35, 508-526. 
Gouthière B. (2005). A comparative study of the thin capitalization rules in the member states of the European Union and certain other countries. European Taxation 45, 367-451.

Haufler A. and M. Runkel (2012). Firms' financial choices and thin-capitalization rules under corporate tax competition. European Economic Review 56, 1087-1103.

Haufler A., M. Mardan and D. Schindler (2014). An economic rationale for controlledforeign-corporation rules. Mimeo. University of Munich.

Holmstrom B. and J. Tirole (1997). Financial intermediation, loanable funds and the real sector. Quarterly Journal of Economics 112, 663-691.

Hong Q. and M. Smart (2010). In praise of tax havens: international tax planning and foreign direct investment. European Economic Review 54, 82-95.

Huizinga H., L. Laeven and G. Nicodème (2008). Capital structure and international debt shifting. Journal of Financial Economics 88, 80-118.

Janeba E. and M. Smart (2003). Is targeted tax competition less harmful than its remedies?. International Tax and Public Finance 10, 259-280.

Keuschnigg C. and E. Ribi (2013). Profit taxes and financing constraints. International Tax and Public Finance 20, 808-826.

Keuschnigg C. and M.P. Devereux (2013). The arm's length principle and distortions to multinational firm organization. Journal of International Economics 89, 432440.

Manova K. (2013). Credit constraints, heterogeneous firms, and international trade. Review of Economic Studies 80, 711-744.

Matsuyama K. (2007). Credit Traps and Credit Cycles. American Economic Review $97,503-516$.

Mintz J. and M. Smart (2004). Income shifting, investment, and tax competition: theory and evidence from provincial taxation in Canada. Journal of Public Economics 88, 1149-1168. 
Møen J., D. Schindler, G. Schjelderup and J. Tropina (2011). International Debt Shifting: Do Multinationals Shift Internal or External Debt? CESifo Working Paper No. 3519.

Overesch M. and G. Wamser (2010). Corporate tax planning and thin capitalization rules: evidence from a quasi-experiment. Applied Economics 42, 562-573.

Peralta S., X. Wauthy and T. Van Ypersele (2006). Should countries control international profit shifting? Journal of International Economics 68, 24-37.

Rajan R. and L. Zingales (1998). Financial dependence and growth. American Economic Review 88, 559-586.

Ruf M. and D. Schindler (2012). Debt shifting and thin-capitalization rules - German experience and alternative approaches. NHH Discussion Paper RRR 2012-06, Bergen.

Schindler D. and G. Schjelderup (2013). Transfer pricing and debt shifting in multinationals. CESifo Working Paper No. 4381.

Wamser G. (2014). The impact of thin-capitalization rules on external debt usage a propensity score matching approach. Oxford Bulletin of Economics and Statistics 76, 764-781.

Weichenrieder A. and H. Windischbauer (2008). Thin-capitalization rules and company responses - experience from German legislation. CESifo Working Paper No. 2456.

von Hagen J. and H. Zhang (2014). Financial development, international capital flows, and aggregate output. Journal of Development Economics 106, 66-77. 